Management international

International Management

Gestiòn Internacional

Beyond Dichotomy: The Curvilinear Impact of Employee

Ownership on CEO entrenchment

L'effet curvilinéaire de l'actionnariat salarié sur

l'enracinement des dirigeants

Más allá de la dicotomía: El impacto curvilíneo de la propiedad de los empleados sobre el atrincheramiento de los CEO

\author{
Xavier Hollandts, Nicolas Aubert, Abdelmehdi Ben Abdelhamid et Victor \\ Prieur
}

Volume 22, numéro 2, hiver 2018

URI : https://id.erudit.org/iderudit/1058165ar

DOI : https://doi.org/10.7202/1058165ar

Aller au sommaire du numéro

Éditeur(s)

HEC Montréal

Université Paris Dauphine

ISSN

1206-1697 (imprimé)

1918-9222 (numérique)

Découvrir la revue

Citer cet article

Hollandts, X., Aubert, N., Ben Abdelhamid, A. \& Prieur, V. (2018). Beyond

Dichotomy: The Curvilinear Impact of Employee Ownership on CEO

entrenchment. Management international / International Management / Gestiòn

Internacional, 22(2), 112-127. https://doi.org/10.7202/1058165ar
Résumé de l'article

L'actionnariat salarié est susceptible d'avoir un impact majeur sur la gouvernance des entreprises. En effet, ces mécanismes peuvent s'avérer décisifs pour faire échouer une prise de contrôle hostile ou pour permettre aux dirigeants d'écarter les menaces de renvoi. Dans le cadre de cet article, nous examinons le lien potentiel entre actionnariat salarié et enracinement managérial. Notre étude empirique examine cette question au moyen d'un échantillon d'entreprises cotées, analysées sur une période récente (2009-2012). Nos résultats montrent la présence d'une relation significative en U inversé entre le niveau d'actionnariat salarié et l'enracinement managérial. La présence de représentants des actionnaires salariés au sein des conseils d'administration ou de surveillance a également un impact en faisant varier les points d'inflexion des relations observées.
Tous droits réservés (C) Management international / International Management / Gestión Internacional, 2018
Ce document est protégé par la loi sur le droit d'auteur. L’utilisation des services d'Érudit (y compris la reproduction) est assujettie à sa politique d'utilisation que vous pouvez consulter en ligne. 


\title{
Beyond Dichotomy: The Curvilinear Impact of Employee Ownership on CEO entrenchment ${ }^{\star}$
}

\author{
L'effet curvilinéaire de l'actionnariat salarié sur \\ l'enracinement des dirigeants
}

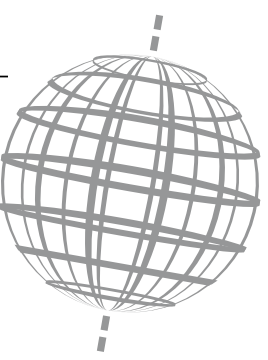

\section{Más allá de la dicotomía: El impacto curvilíneo de la propiedad de los empleados sobre el atrincheramiento de los CEO}

\author{
XAVIER HOLLANDTS \\ KEDGE BS \& CRCGM, \\ France
}

\author{
NICOLAS AUBERT \\ Aix Marseille University, \\ CERGAM, IAE, Puyricard, \\ France \& INSEEC Business \\ School
}

\author{
ABDELMEHDI BEN \\ ABDELHAMID \\ Clermont Auvergne \\ University \& CRCGM, \\ France
}

\author{
VICTOR PRIEUR \\ Paris Dauphine University, \\ France \& King's College, \\ London UK
}

\section{ABSTRACT}

Employee stock ownership gives employees a voice and therefore may have a major impact on corporate governance. Thus, employee stock ownership may be a powerful mean to protect CEOs from both market for corporate control and dismissal threat. In this paper, we examine the relationship between employee stock ownership and CEO entrenchment. Following the recent French legislative changes, we use a comprehensive panel dataset of the major French listed companies over the 2009-2012 period. We document inverted U-shaped relationships between employee stock ownership and CEO entrenchment. Board employee ownership representation also plays a role and increases the inflexion points of these curvilinear relationship.

Keywords: employee stock ownership, corporate governance, CEO entrenchment.

\section{RÉSUMÉ}

L'actionnariat salarié est susceptible d'avoir un impact majeur sur la gouvernance des entreprises. En effet, ces mécanismes peuvent s'avérer décisifs pour faire échouer une prise de contrôle hostile ou pour permettre aux dirigeants d'écarter les menaces de renvoi. Dans le cadre de cet article, nous examinons le lien potentiel entre actionnariat salarié et enracinement managérial. Notre étude empirique examine cette question au moyen d'un échantillon d'entreprises cotées, analysées sur une période récente (2009-2012). Nos résultats montrent la présence d'une relation significative en $U$ inversé entre le niveau d'actionnariat salarié et l'enracinement managérial. La présence de représentants des actionnaires salariés au sein des conseils d'administration ou de surveillance a également un impact en faisant varier les points d'inflexion des relations observées.

Mots-Clés : actionnariat salarié, gouvernance de l'entreprise, enracinement des dirigeants

\section{RESUMEN}

La propiedad de acciones de los empleados da voz a los empleados y por lo tanto puede tener un impacto importante en el gobierno corporativo. Por ello, la propiedad de acciones por parte de los empleados puede ser un poderoso medio para proteger a los CEO tanto del mercado para el control corporativo como de la amenaza de despido. En este artículo, examinamos la relación entre la propiedad de acciones de los empleados y el afianzamiento del CEO. Tras los recientes cambios legislativos franceses, utilizamos un amplio conjunto de datos de panel de las principales empresas francesas cotizadas durante el periodo 2009-2012 y encontramos una relación con forma de $\mathrm{U}$ invertida entre la propiedad de acciones de los empleados y el afianzamiento del CEO. La representación de la propiedad del empleado en la junta también desempeña un papel relevante al incrementar el punto de inflexión de esta relación curvilínea.

Palabras Clave: ppropiedad de acciones de empleados, gobierno corporativo, atrincheramiento CEO
$\mathrm{E}$ mployee stock ownership (ESO from now) is a powerful tool sometimes presented as a way to promote shared capitalism (Kruse et al, 2010). When a firm makes some profits, part of them are usually plowed back and retained (self-financing), and some are shared among shareholders and, for a minor part, employees. With ESO schemes, employees are offered a part of profits, which allows them to increase their personal wealth, being better associated with the firm's success. The success of ESO mechanism is undeniable (Kim and Ouimet, 2014) and for instance, 23 millions of American employees (20\% of total employee workforce - National Center for ESO, 2014) are employee owners. In France, we estimate to almost 3.5 millions

\footnotetext{
* Acknowledgments:

We wish to thank for their valuable comments and suggestions the anonymous reviewers of Management international. We are also indebted to the Editor in Chief Patrick Cohendet for his support through the whole reviewing process. All remaining errors are our own.
} 
of French employee owners ${ }^{1}$. This success can be analyzed as an evidence of a "shareholder capitalism" since there are more and more shareholders in the world and employee owners take part of this worldwide and enduring phenomenon.

The decision of implementing and developing ESO often lies with management. Executive managers have a discretionary power to implement such schemes (Scholes and Wolfson, 1990). Managers have two major motivations to reward their employees with stock: to incentivize them to enhance corporate performance (Kim and Ouimet, 2014) and to retain them (Rauh, 2006). Indeed, the academic literature presents ESO as a two-edged sword. On one hand, ESO may be used as a reward management tool to enhance corporate performance through its incentive effects. Kaarsemaker (2006) summed up the literature on attitudinal effects of ESO and shows that employee owners are more satisfied, involved, productive, exhibit lower turnover and absenteeism rates and are likely to less free-ride On the other hand, it may be a management entrenchment mechanism via the potential collusion between employee owners and management. The impact of ESO on corporate governance is still being debated in the literature. One can argue that the presence of ESO has a positive impact because it decreases the overall level of asymmetric information of shareholders (Acharya et al, 2011). Besides, Faleye et al (2006) underline the "darks side" of ESO leading to management entrenchment and decreased shareholder value. Employee owners may protect executive managers with a friendly part of capital (Gamble, 2000). Thus, executive managers can reward employee owners with their protection, better job conditions or salaries (Cronqvist et al, 2009). In this configuration, employee owners can entrench themselves as CEOs do.

A large body of the literature examined the "dark side" of ESO (Gordon and Pound 1990; Chaplinsky and Niehaus, 1994; Park and Song, 1995; Gamble, 2000; Hellwig, 2000; Pagano and Volpin, 2005; Benartzi et al, 2007) but focuses mainly on the potential impact on corporate performance and governance. Our paper addresses also the question of the impact of ESO on governance by adding one new dimension of employee voice with their compulsory participation as board members in French boards. Some papers have examined the consequences of significant ESO on performance, risk, productivity or growth (Faleye et al, 2006; Park and Song 1995), on corporate takeovers (Pagano and Volpin 2005, Chaplinsky and Niehaus 1994), R\&D intensity (Gamble, 2000). The test provided in such papers always examined the impact of employee share ownership on several dimensions of corporate governance and corporate performance. In our paper, we suggest to expand the consequences of ESO by considering the impact of "employee voice", namely the potential combination of employee share ownership and ESO board membership (Fauver and Fuerst, 2006). French law and corporate governance system have evolved towards compulsory employee owners board membership at the end of 2000s and provide an opportunity to test such consequences of employee ownership's voice. Distinct from German codetermination regime (Fauver and Fuerst 2006), French corporate governance system is often presented as an hybrid system between Anglo-Saxon corporate governance regimes and Nordic and German corporate governance systems (Aste, 1999; Ginglinger et al, 2011). In this regard, "employee voice" may appear as a powerful mean for executive managers to increase their personal entrenchment (Faleye et al, 2006; Fauver and Fuerst, 2006; Gamble, 2000; Park and Song, 1995). Combining both the bright and dark side, we suggest that the impact of ESO and board employee ownership representation (BEOR from now) could be non-monotonic. In this paper, we investigate this issue by addressing the following research question: Does ESO affect CEO entrenchment? This impact can be split in two directions: Is ESO linked to CEO entrenchment? As ESO gives a voice to employee owners through potential board membership: Is board ESO participation linked to CEO entrenchment?

The novelty of our empirical results is to document a non-monotonic relationship between ESO and several measures of CEO entrenchment: CEO age, CEO tenure and CEO turnover. We also underline that BEOR increases the effect of ESO on CEO entrenchment by increasing the inflexion points of the curves. BEOR then plays a role in providing CEOs with an additional entrenchment tool. The remainder of the paper is organized as follows. Section 1 reviews the literature on the relationships between ESO, corporate governance and CEO entrenchment. Section 2 presents the methodology and the sample. Section 3 outlines results. Section 4 discusses findings, and section 5 concludes.

\section{Literature review}

\section{ESO And Firm Performance}

Broadly speaking, ESO is a management tool that can help to further enhance shared capitalism. Shared capitalism refers to "plans that tie worker pay or wealth to the performance of their own workplace" (Kruse et al, 2010; p. 5). In their book, Kruse et al (2010) investigate shared capitalism based on a representative sample of US workforce of more than 40,000 employees. They find evidence of the positive relationship between shared capitalism mechanisms including ESO and corporate performance. By giving employees a residual claim, it fosters positive job attitudes in the workplace, which therefore improves corporate performance. From an organizational perspective, ESO enhances cooperation and mutual monitoring within the workplace, increases productivity, decreases turnover and absenteeism. In his extensive literature review, Kaarsemaker (2006) concludes that most of the academic literature finds a

1. French workers have different ways to buy stocks of the company they work for. First, employees can invest in their company stocks simply by buying them directly from the financial market. The most common way to become an employee owner is to invest in a company savings plan (CSP or Plan d'Epargne Entreprise in French). Amounts that can be invested are the profit-sharing or gainsharing bonuses or the voluntary contributions. Investing in a PEE is financially rewarding for the employees for two reasons. First, money invested in the CSP by the employee can be matched by an employer contribution. Second, in the case of an employee stock purchase plan (ESPP), employees who buy stocks can benefit from a maximum discount of $20 \%$ on the stock price. The money invested in the CSP are frozen for a minimum of 5 years and they benefit from fiscal advantages. A major difference between the French CSP and the US ESOP is that the latter are mostly implemented by small and medium sized companies whereas a large majority of the French employee owners work for large listed companies. The ESOP also differs from the CSP in that it is only invested in company stocks. The CSP offers several alternative options. When setting up an ESPP, most French companies attribute the maximum discount combining them with matching contribution in company stock (see Rapp and Aubert, 2008 for more details and Ginglinger et al, 2011 for a focus on corporate governance). 
positive relationship between ESO, employee attitudes and several firm performance measures. This is the bright side of ESO: a set of positive incentive mechanisms that foster various positive employee attitudes at work, thus improving corporate performance. In addition, ESO tends to retain human capital and to increase employee loyalty (Blair et al, 2000). Regarding corporate governance, ESO has unclear impacts due to the presence of bright and dark side effects.

\section{ESO AND INTERNAL GOVERNANCE}

Indeed, as insider equity ownership, ESO has an intriguing role. ESO exhibits positive effects and can reduce CEOs' opportunistic behaviors since employee owners have an intimate knowledge of their organization (Acharya et al, 2011). By sharing information with external shareholders, they may mitigate asymmetric information. The internal governance of the firm can "force a self-interested CEO to act in a more public-spirited and far-sighted way" (Acharya et al, 2011; p. 689). In the same vein, Adams and Ferreira (2007) show that the natural proximity with internal stakeholders as employees also contributes to a more efficient corporate governance since it helps to decrease the level of asymmetric information. For instance, Bova et al (2015) show that firms with ESO are more transparent and exhibit better disclosure. ESO also gives a strong incentive to monitor executive managers since a big part of employee owners' personal wealth directly depends on corporate decision makers (Blair, 1999; Kruse et al, 2010). Because ESO often represents a cost in terms of portfolio diversification (Yi Tsung et al, 2008), employee owners pay particular attention to the top management's decisions of their company. In this configuration, there is a potential alignment of interests for the main firm's stakeholders (employees, shareholders, executive managers) towards performance maximization. In fact, ESO helps to mitigate agency problems, mainly by reducing free-riding problems and incentivizes employees towards improved corporate performance (Kruse et al, 2010; Guedri and Hollandts, 2008). Nevertheless, a large body of the literature has shown that ESO also exhibits a dark side regarding corporate governance.

\section{ESO AND Bilateral ENTRENCHMENT: Is THERE A DARK Side?}

However, ESO also exhibits what Faleye et al (2006) call a dark side referring to its effects on corporate governance. Some authors argue that ESO is a powerful entrenchment tool because it reduces the probability of a takeover (Beatty, 1995) ${ }^{2}$. The "natural alliance" between employees and managers (Hellwig, 2000) encourages CEOs to establish implicit contracts with employee shareholders (Pagano and Volpin, 2005) in exchange for a friendly control of employee owners (Benartzi et al, 2007; Gamble, 2000). From this standpoint, ESO prevents an efficient market for corporate control (Chaplinsky and Niehaus, 1994; Park and Song, 1995).

Gordon and Pound (1990) consider that many ESOPs were established in the US in the late 1980s, explicitly to deter takeovers. Employee owners tend to vote against takeovers since they often go along with layoffs. Negative effects of ESO on corporate governance are well documented empirically. Indeed, ESO is more powerful than poison pills or golden parachutes (Chaplinsky and Niehaus, 1994) and other defensive mechanisms are less likely to be used when a firm already offers ESO schemes (Rauh, 2006; Park and Song, 1995). Besides, financial markets tend to react negatively to an ESOP's implementation announcement (Chang, 1990; Chang and Mayers, 1992), especially when they appear as a mean to entrench management (Cramton et al, 2008). Faleye et al (2006) argue that such a protection is more general, underlining that the dark side of ESO leads to a "bilateral entrenchment": CEOs may be more easily entrenched with ESO, but employees also tend to entrench themselves, benefitting from the CEOs' protection against layoffs (Atanassov and Kim, 2009). This is why ESO works as an insurance mechanism that ensures favorable employment policies and limits the risk of redundancies or wage cuts (Kim et al, 2014). In return, employee owners stand ready to help their CEO to fight off a potential takeover bid and his subsequent dismissal (Chaplinsky and Niehaus, 1994; Pugh et al, 1999). This mutual protection and commitment between executive managers and employee owners is set up on the terms of an implicit contract (Acharya et al, 2011; Atanassov and Kim, 2009; Pagano and Volpin, 2005). Employee owners can grant protection to their CEO since they control part of the capital and exercise their voting rights. As part of these implicit contracts, CEOs tend to implement policies aimed at maintaining or increasing levels of employment and wages (Faleye et al, 2006). In this regard, Cronquist et al (2009) show that CEOs who wish to reach higher entrenchment levels, choose to better reward their employees in an attempt to reach "social peace". Therefore, shareholders pay this potential collusion with higher wages granted to employees, and a lower probability of receiving a takeover premium (Kim and Ouimet 2014, Faleye et al, 2006). Kim and Ouimet (2014, p. 1277) explicitly suggest that "management bribes employee with higher wages to garner worker support to thwart hostile takeover bids". This configuration, allows CEOs to have a "quiet life" by avoiding confrontations with external shareholders or the market for corporate control (Bertrand and Mullainathan, 2003). More precisely, Aubert et al (2014) consider that the incentive to increase managerial entrenchment by the mean of ESO may vary regarding to the corporate governance context. More specifically, it seems that the incentive for CEOs could vary depending on the corporate performance and on their level of managerial entrenchment. Increasing ESO would be less motivating for well-entrenched or/and high performer CEOs (Gregory-Smith et al, 2009).

\section{ESO on CEO Entrenchment: a Curvilinear RELATIONSHIP?}

The combination of two latent functions (namely the bright and dark side of ESO described above) could therefore leads to a non-monotonic relationship between ESO and CEO entrenchment. Haans et al (2016) deeply explained the rationale of quadratic relationships ${ }^{3}$. A U-shaped relationship may

2. In this paper, we consider that entrenchment has mainly negative effects on corporate governance (Morck et al, 1988; McConnell \& Servaes, 1990) since the vast majority of corporate governance literature analyses it as a deviation from optimal configuration from an agency perspective (Fisman et al, 2013; Joseph et al, 2014 and Tihanyi et al, 2014). We acknowledge that there is a theoretical debate on the impact of CEO entrenchment since the seminal paper of Castanias and Helfat (1992) underlines that, in some circumstances, managerial entrenchment can create value for the firm and its shareholders.

3. We thank the anonymous reviewer that point out this very useful reference. 
be conceptualized as two latent functions jointly making up a quadratic. While the latent functions are commonly not observable, they may be combined either additively or multiplicatively to explain a quadratic relationship that reveals the "net effect" of X on Y (Haans et al, 2016; p. 1178-79). In this paper, we consider that on one hand that the bright side of ESO mitigates agency problems, increases transparency and decreases the level of asymmetric information. But on another hand, ESO also exhibits a dark side. ESO can lead to a friendly control benefitting to the CEO. ESO can also be detrimental to external shareholders due to higher wages and less efficiency of corporate governance mechanisms. Thus, the net effect of the bright and dark side can be translated in a non-monotonic function between ESO and corporate governance efficiency. We suggest that this U-shaped relationship can be observed for one major corporate governance variable namely the CEO entrenchment. Two opposite forces can be at play and thus the relationship between ESO and CEO entrenchment can exhibit a U-shaped relationship. Thus, in this paper, we suggest that two opposite forces (the bright side - positive function and dark side - negative function) interact and thus a U-shaped relationship emerges due to the combination of two latent linear functions as described in Haans et al (2016). Regarding the shape of the relationship between ESO and governance, several recent papers underline that ESO exhibits non-linear relationships. Faleye et al (2006) test the impact of significant ESO (over $5 \%$ of share capital) on corporate performance, valuation, investment and risks ${ }^{4}$. They show that large ESO pushes away rather than towards shareholder-value maximization. Kim and Ouimet (2014) indicate that small ESOPs (under 5\% of shares) tend to increase the size of the overall economic pie, benefitting both employees and shareholders. In their study, the positive effects of ESO occur at the threshold of 5\% of the capital held by employees, and effects are much weaker for large ESOPs. Over this threshold, these gains are absorbed by higher wages (Cronqvist et al, 2009). Recent papers reveal the presence of a curvilinear relationship (Guedri and Hollandts, 2008) or at least of a 5\% threshold (Faleye et al, 2006; Kim and Ouimet, 2014). Guedri and Hollandts (2008) also suggest that the presence of BEOR can moderates the relationship between ESO and performance and thus "employee voice" can play a crucial role. Also in the French context, Ginglinger et al (2011) test the impact of employee owners' representation on the board and find that it is at least value-neutral. In order to optimize corporate performance, the theoretical optimum level of ESO results from the combination of small levels of ESOPs that guarantee optimal incentives for employees and have low consequences in terms of free-riding problems (Kim and Ouimet, 2014; Aubert et al, 2014; Ginglinger et al, 2011; Guedri and Hollandts, 2008). Regarding the level of CEO entrenchment, Aubert et al, (2014) argue that ESO is a powerful entrenchment mechanism for low-performing CEOs and may be less useful for high-performing or well-entrenched CEOs.

To sum up, the link between ESO and managerial entrenchment exhibits two opposing forces. As ESO exhibits bright side and dark side over corporate governance and performance, we suggest that two latent function are at play and can be translated in a curvilinear relationship between employee ownership and CEO entrenchment. Therefore, we state the following hypothesis:

H1: ESO exhibits a non-monotonic relationship with CEO entrenchment. ESO is positively related to CEO entrenchment across the low to moderate levels of ESO, and is negatively related to CEO entrenchment across the moderate to high levels of ESO.

Another consequence of ESO consists in giving a "voice" to employee owners since they can be offered seats on the board of directors. Hence, employee owners' representation could foster CEO entrenchment. In most European countries, employee owners can be represented on the board of directors or on the supervisory board (e.g. Germany and the co-determination system: Kim et al, 2014; Fauver and Fuerst, 2006). At the end of 2006, representation of employee owners on the board of directors became compulsory for French listed companies (Ginglinger et al, 2011) if employee owners collectively hold over $3 \%$ of shares, the general meeting of shareholders must give at least one seat to an employee owners' representative. BEOR is often viewed as an additional voice available to employee owners and as the recognition of ESO. When coupled with BEOR, ESO provides CEOs with an additional entrenchment tool (Gordon and Pound, 1990; Pugh et al, 1999). The natural alliance between employees and managers encourages CEOs to establish implicit contracts with employee owners (Pagano and Volpin, 2005), including eventual protection from employee owners during the meetings of the board of directors (Guedri and Hollandts, 2008; Ginglinger et al, 2011). From the perspective of employee owners, it is much easier to lobby in favor of policy decisions that maximize their own interests if they have at least one seat on the board of directors. In exchange for support from employee owners (Atanassov and Kim, 2009; Fauver and Fuerst, 2006), CEOs would implement corporate policies aimed at increasing the level of employment and wage rate (Faleye et al, 2006; Cronqvist et al, 2009). As a consequence, employee owners and CEOs have a direct interest to set up mutual protection mechanisms. This is why there is a potential risk of "bilateral entrenchment" notably at board level (Ginglinger et al, 2011; Faleye et al,2006). As BEOR is the consequence of significant levels of ESO (at least 3\% of capital), potential implicit contracts can be established between employee owners board members and CEOs (Guedri and Hollandts, 2008). Therefore, we suggest that BEOR increases the potential relationship between ESO and CEO entrenchment. In other words, BEOR gives an additional mean of entrenchment to CEOs. Following Guedri and Hollandts (2008), we suggest that the presence of employee owners into the board is likely to facilitate friendly control and alliance between CEOs and employee owners' board members. Hence, BEOR seems to positively moderate the relationship between ESO and CEO entrenchment and thus the inflection point is likely to occur at lower level of ESO. We therefore put the following hypothesis:

H2: Board employee owners' representation positively moderates the non-monotonic relationship between ESO and CEO entrenchment.

4. In their seminal paper, Mc Connel \& Servaes (1990) have shown a similar curvilinear relationship between corporate insiders (executive managers and board members) and performance (Tobin's Q). 


\section{Data and Methods}

In this section, we present an empirical examination of the relationship between ESO, BEOR, and CEO entrenchment. We take into account variables that may affect this relationship and we test our research hypotheses based on the 120 largest French listed companies (SBF 120 index).

\section{DATA}

Our panel comprises two types of data sources. First, we used the INSEAD OEE Data Services (IODS) corporate governance, based on the 120 largest French capitalizations. This data was previously used by Ginglinger et al (2011). Among other variables we use in this paper and that we will detail further, the IODS dataset provides the proportion of equity hold by the employees and the BEOR. We match corporate governance variables with data from Thomson Reuters Eikon. Our dataset is longitudinal and covers the 2009-2012 period. It starts in 2009 due to the gap between the 2006 act on BEOR and its actual enforcement. Indeed, the French government established a two-year period to enforce the law (end of enforcement: 31/12/2008). Our data include the CEO entrenchment variables between 2009 and 2012. The description of all the variables included in the regressions is given in table 1.

\section{Dependent Variables: CEO Entrenchment}

The degree of managerial entrenchment was operationalized using three variables (Linck et al, 2008). The first one encompasses the number of years the CEO has filled his/her position within the company (Hill and Phan, 1991). Several studies have shown that a high CEO longevity makes him/her more resistant to internal and external pressures from different stakeholders. This longevity allows the CEO to exert an influence, in his/her own favor, on the decision process leading to the governance structure (Hermalin and Weisbach, 2000; Boone et al, 2007). We also included the CEO's age variable. The CEO's age impacts his/her managerial entrenchment strategy, especially when retirement becomes closer (Goyal eand Park, 2002). We finally introduce a last variable measuring CEO entrenchment using turnover (Faleye, 2007). This variable takes the value of one if there is a CEO dismissal for a given year and 0 otherwise.

\section{INDEPENDENT VARIABLES: EMPLOYEE STOCK AND BOARD EMPLOYEE OWNERSHIP REPRESENTATION}

ESO is a continuous variable that measures the level of ESO as the percentage of outstanding equity hold by employees for a given year (Aubert et al, 2014; Kruse et al, 2010). The percentage of ESO as a proxy for its size is crucial to examine the relationship between ESO and CEO entrenchment (Kim and Ouimet, 2014). BEOR is measured by the total number of employee owners divided by the size of the board i.e. the number of people seating on the board (Fauver and Fuerst, 2006). In French firms, board employee representation cannot exceed a third of board members, and this configuration cannot be assimilated to the co-determination system (Guedri and Hollandts, 2008). The French corporate governance system is sometimes seen as a "hybrid" pattern (Aste, 1999), midway between systems without any employee representation and the German pattern where two-tiered boards and employee representation are compulsory.

\section{Control Variables: Governance, FinANCIAL AND Sectoral Characteristics}

We introduce two kinds of control variables in our regression analyses: corporate governance variables and financial and sectoral characteristics. We first control for corporate governance characteristics: the ownership concentration, the French state ownership, the family ownership, the proportion of external directors on the board, the board size, the CEO duality and the presence of a two tiered board. These corporate governance variables may influence the focal relationship between the voice given to employees and CEO entrenchment. They are related to the ability of the CEO to be entrenched. The ownership concentration is measured by the largest shareholder (Hill and Snell, 1988). State and family ownership are two dummy variables taking the value of one if the French State of the founding family holds stocks of the company. These three ownership variables, by affecting management discretionary power, potentially affect CEO entrenchment. The board size is the total number of board members (Yermack, 1996) and is expected to increase entrenchment. The proportion of outside board members is also included (Raheja, 2005) because it is assumed to decrease entrenchment. We follow Adams et al (2010) who define outside board members as people with any current or past relationships with the focal firm (as employees, supplier, client or consultant $)^{5}$. CEO duality is also measured. Duality is when the CEO and chairman positions are not hold by the same person. A last variable controls for the structure of the board. In France companies have the choice between a two tiered board or a unitary board structure. On another hand, we use variables controlling for financial and sectoral characteristics of the companies. The return on equity and the Tobin's Q account for accounting and financial performance respectively because they affect the managerial entrenchment strategy as predicted by the model of Aubert et al (2014). The sales variable captures size effects (Boone et al, 2007) and two dummies capture to which sector the company belongs. Sec1 is a dummy taking the value of 1 if the company belongs to the industrial sector (raw material, industry, consumption goods). Sec2 is a dummy taking the value of 1 if the company belongs to the service sector (health services, consumer services, telecommunication, services to communities).

\section{MeTHODS}

We use panel GMM estimators to alleviate endogeneity concerns. Indeed, corporate governance research is subject to endogeneity issues since the investigated variables are endogenous by nature as it is extensively documented by Baghat and Jeffries (2005). GMM estimator was developed in a series of papers (Arellano and Bond, 1991; Blundell and Bond, 1998) and improves fixed-effects OLS estimates when endogenous variables are included in regressions (Wintoki et al, 2012). Endogeneity can occur in OLS regression and may be the consequence of five different

5. In addition, this proxy of outsiderness encompasses the definition mainly used in French corporate governance codes (AFEP/MEDEF code, following Vienot and Bouton reports). Out of 120 listed companies, 108 made explicit reference to AFEP/MEDEF code to classify board members as outsiders. 


\begin{tabular}{|c|c|c|c|}
\hline \multicolumn{4}{|c|}{$\begin{array}{c}\text { TABLE } 1 \\
\text { Description of variables }\end{array}$} \\
\hline Variable name & Source & Description & Measurement unit \\
\hline \multicolumn{4}{|c|}{ Dependent variables: CEO entrenchment } \\
\hline CEO age & IODS corporate governance & CEO age is the age of CEO & Years \\
\hline CEO tenure & IODS corporate governance & CEO tenure is the time the CEO has spent in position & Years \\
\hline CEO turnover & IODS corporate governance & CEO turnover indicates if a CEO dismissal happens (1) or not (0) & Binary 0/1 \\
\hline \multicolumn{4}{|c|}{ Independent variables: Employee stock ownership and employee stock ownership representation on the boards } \\
\hline ESO & IODS corporate governance & ESO is the percentage of shares held by employees. & Percentage \\
\hline BEOR & IODS corporate governance & BEOR is the proportion of employee owners seating on the board & Percentage \\
\hline \multicolumn{4}{|c|}{ Control variables: corporate governance and financial characteristics } \\
\hline $\begin{array}{l}\text { Own. } \\
\text { concentration }\end{array}$ & IODS corporate governance & $\begin{array}{l}\text { Own. Concentration measures the percentage of equity held by the } \\
\text { largest shareholder }\end{array}$ & Percentage \\
\hline $\begin{array}{l}\text { External } \\
\text { directors }\end{array}$ & IODS corporate governance & $\begin{array}{l}\text { External director is the number of external directors divided by the } \\
\text { total board members }\end{array}$ & Percentage \\
\hline Board size & IODS corporate governance & Board size is the total number of board members & Number \\
\hline CEO duality & IODS corporate governance & $\begin{array}{l}\text { CEO duality is the dummy variable taking the value of } 1 \text { if the CEO } \\
\text { is also the chairman and } 0 \text { otherwise }\end{array}$ & Binary 0/1 \\
\hline $\begin{array}{l}\text { Dual } \\
\text { Structure }\end{array}$ & IODS corporate governance & $\begin{array}{l}\text { Dual structure takes the value of } 1 \text { if the company has a two tiered } \\
\text { board structure and } 0 \text { otherwise }\end{array}$ & Binary $0 / 1$ \\
\hline State & IODS corporate governance & $\begin{array}{l}\text { State is the dummy variable taking the value of } 1 \text { if the state holds } \\
\text { shares of the company and } 0 \text { otherwise }\end{array}$ & Binary $0 / 1$ \\
\hline Family & IODS corporate governance & $\begin{array}{l}\text { Family is a dummy variable taking the value of } 1 \text { if the company is } \\
\text { owned by the family and } 0 \text { otherwise }\end{array}$ & Binary 0/1 \\
\hline ROE & Thomson Reuters Eikon & ROE is the return on equity & $\begin{array}{l}\text { Log of a } \\
\text { percentage }\end{array}$ \\
\hline Sales & Thomson Reuters Eikon & Sales is the total sales of the company in euros & $\begin{array}{l}\text { Log of the amount } \\
\text { in Euros }\end{array}$ \\
\hline Tobin's Q & Thomson Reuters Eikon & $\begin{array}{l}\text { Tobins' } Q \text { is defined as the market value of equity at the end of the } \\
\text { fiscal year plus the book value of assets minus the book value of } \\
\text { equity, all divided by the book value of assets }\end{array}$ & Proportion \\
\hline Sec1 & Thomson Reuters Eikon & $\begin{array}{l}\text { Sec1 is a dummy taking the value of } 1 \text { if the company belongs to } \\
\text { the industrial sector (raw material, industry, consumption goods) }\end{array}$ & Binary $0 / 1$ \\
\hline Sec2 & Thomson Reuters Eikon & $\begin{array}{l}\text { Sec2 is a dummy taking the value of } 1 \text { if the company belongs to } \\
\text { the service sector (health services, consumer services, } \\
\text { telecommunication, services to communities). }\end{array}$ & Binary 0/1 \\
\hline
\end{tabular}

issues: error-in-variables (measurement error), autoregression, omitted variables, simultaneous causality and reverse causality (Wintoki et al, 2012; Semadeni et al, 2014). In each of these scenarios, OLS regression reports biased coefficients. Instead of estimating the true relationship between the independent variable and the dependent variable, OLS regression mistakenly includes the correlation between the independent variable and the error term in the estimation of the independent variables' coefficients. As most empirical corporate governance studies, our research model is likely to be affected by endogeneity. First, we can never totally exclude the risk of simultaneous causality. Second, we cannot also exclude that if ESO and BEOR affect CEO entrenchment, the reverse can also occur. In fact, CEO with long tenure and close to retirement can have developed ESO for years. Regarding unobservable heterogeneity (factors that affect both dependent and independent variables), OLS regression results can report spurious but statistically significant estimates (Wintoki et al, 2012). In the case of dynamic relation between an explanatory variable and past realizations of the dependent variable, a fixed-effect regression may be biased and the direction of the bias will be opposite of the dynamic relation. GMM panel estimator exploits the dynamic relationship inherent in our explanatory variables and the dynamic relation between our independent variables and CEO entrenchment. This problem is severe in corporate governance research and again GMM estimators can provide unbiased estimates (Wintoki et al, 2012).

\section{Results}

\section{Descriptive Statistics}

Descriptive statistics are displayed in table 2. The median age of CEOs is 56 years and they hold their position for 4,71 years on average. The average percentage of equity hold by employees is $2,41 \%$, which is higher than in previous studies: $1,62 \%$ for Guedri and Hollandts (2008) and 1,63\% for Ginglinger et al (2011). This difference is due to the time window of our study which focuses on recent years whereas previous studies cover older periods, ending respectively in 2005 and 2008 . The fact that ESO is, by essence, cumulative (Blair et al, 2000) means that firms have experienced continuous ESO schemes for the last years. The mean proportion of BEOR for the whole sample corresponds to $2.2 \%$ and only 34 firms (out of 110) experienced BEOR. Regarding 
TABLE 2

Descriptive statistics of the variables included in the regression analyses

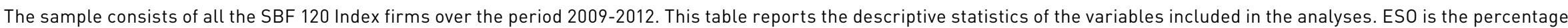

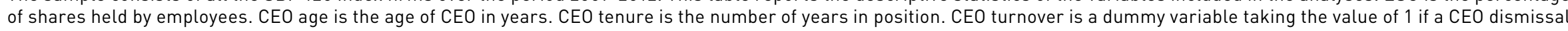

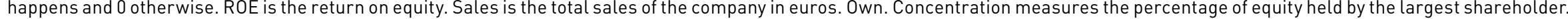

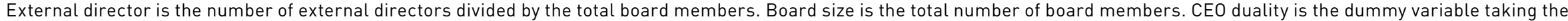

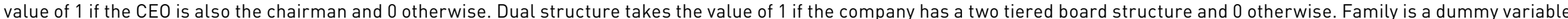

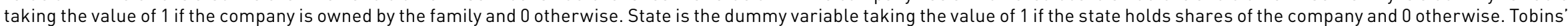

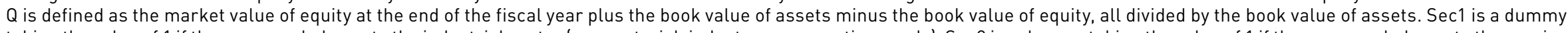

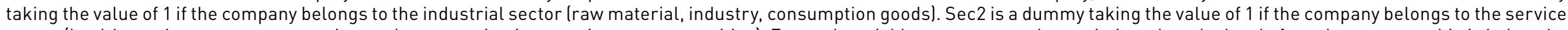

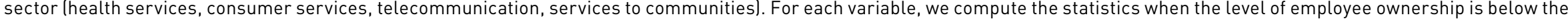
median (<MED) and above the median (>MED). ${ }^{* * *},{ }^{* *},{ }^{*}$ indicate coefficients significant at the $1 \%, 5 \%$, and $10 \%$ levels, respectively.

\begin{tabular}{|c|c|c|c|c|c|c|c|c|c|c|c|c|c|c|c|c|c|c|c|}
\hline & \multicolumn{3}{|c|}{$\mathbf{N}$} & \multicolumn{3}{|c|}{ MEAN } & \multirow{2}{*}{$\begin{array}{l}\text { T-test } \\
\text { <MED - } \\
\text { >MED }\end{array}$} & \multicolumn{3}{|c|}{ MEDIAN (MED) } & \multicolumn{3}{|c|}{ SD } & \multicolumn{3}{|c|}{ MIN. } & \multicolumn{3}{|c|}{ MAX. } \\
\hline & <MED & $>$ MED & All & $<$ MED & $>$ MED & All & & $<M E D$ & $>$ MED & All & <MED & $>$ MED & All & <MED & $>$ MED & All & <MED & $>$ MED & All \\
\hline CEO age & 223 & 251 & 474 & 55.48 & 55.92 & 55.72 & -0.7473 & 55 & 56 & 56 & 6.90 & 5.89 & 6.38 & 41 & 43 & 41 & 76 & 72 & 76 \\
\hline CEO tenure & 223 & 251 & 474 & 4.84 & 4.58 & 4.71 & 0.72 & 4 & 4 & 4 & 4.01 & 3.74 & 3.87 & 0 & 0 & 0 & 17 & 17 & 17 \\
\hline ESO & 223 & 222 & 445 & .34 & 4.50 & 2.41 & $-11.5^{* * *}$ & .23 & 2.59 & 1.03 & .34 & 5.37 & 4.33 & 0 & 1.04 & 0 & 1.03 & 28.7 & 28.7 \\
\hline BEOR & 214 & 211 & 476 & 0.7 & 3.7 & 2.2 & $-5.28 * * *$ & 0 & 0 & 0 & 3.86 & 8.15 & 6.5 & 0 & 0 & 0 & 28.54 & 36.84 & 36.84 \\
\hline $\begin{array}{l}\text { Own. } \\
\text { concentration }\end{array}$ & 222 & 220 & 442 & 36.01 & 22.03 & 29.05 & $7.52 * * *$ & 31.44 & 17.4 & 26 & 20.89 & 18.05 & 20.72 & 4.42 & 2.5 & 2.5 & 78.96 & 84.51 & 84.51 \\
\hline $\begin{array}{l}\text { External } \\
\text { directors }\end{array}$ & 223 & 221 & 444 & 37.64 & 45.07 & 41.34 & $-3.15^{* * *}$ & 32.34 & 42.55 & 37.81 & 23.09 & 26.41 & 25.05 & 0 & 0 & 0 & 100 & 94.76 & 100 \\
\hline Board size & 223 & 221 & 444 & 11.73 & 13.54 & 12.63 & $-5.59 * * *$ & 11 & 14 & 12 & 3.23 & 3.55 & 3.51 & 4 & 3 & 3 & 21 & 23 & 23 \\
\hline ROE & 207 & 239 & 446 & 11.55 & 9.59 & 10.50 & $2.09 * *$ & 10.35 & 9.58 & 9.78 & 11.43 & 8.18 & 9.86 & -17.04 & -10.73 & -17.04 & 66.38 & 38.1 & 66.38 \\
\hline Sales & 223 & 252 & 475 & 6129969 & $2.2 \mathrm{e}+7$ & $1.4 \mathrm{e}+7$ & $-7.73 * * *$ & 1914300 & 9387000 & 4220410 & $1 e+7$ & $3 e+7$ & $2.4 \mathrm{e}+7$ & 1119 & 121972 & 1119 & $6.7 e+7$ & $1.8 e+8$ & $1.8 e+8$ \\
\hline Tobin's Q & 198 & 227 & 425 & 1.16 & .79 & .97 & $4.75^{* * *}$ & .85 & .72 & .77 & 1.07 & .41 & .81 & .04 & .054 & 0.04 & 8.02 & 2.40 & 8.02 \\
\hline \multicolumn{7}{|c|}{ Panel B: Dummy variables } & \multicolumn{6}{|c|}{ Yes $(x=1)$} & \multicolumn{7}{|c|}{ No $(x=0)$} \\
\hline \multicolumn{7}{|l|}{ CEO turnover } & \multicolumn{6}{|c|}{9.09} & \multicolumn{7}{|c|}{90.91} \\
\hline \multicolumn{7}{|l|}{ CEO duality } & \multicolumn{6}{|c|}{72.05} & \multicolumn{7}{|c|}{27.95} \\
\hline \multicolumn{7}{|l|}{ Dual Structure } & \multicolumn{6}{|c|}{72.94} & \multicolumn{7}{|c|}{27.06} \\
\hline \multicolumn{7}{|l|}{ Family } & \multicolumn{6}{|c|}{32.77} & \multicolumn{7}{|c|}{67.23} \\
\hline \multicolumn{7}{|l|}{ State } & \multicolumn{6}{|c|}{13.24} & \multicolumn{7}{|c|}{86.76} \\
\hline \multicolumn{7}{|l|}{ Sec1 } & \multicolumn{6}{|c|}{63.87} & \multicolumn{7}{|c|}{36.13} \\
\hline Sec2 & & & & & & & & & 53.7 & & & & & & & 46.22 & & & \\
\hline
\end{tabular}




\section{TABLE 3}

\section{Correlation matrix of the variables included in the regression analyses}

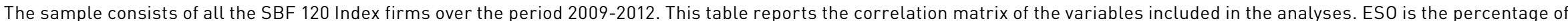

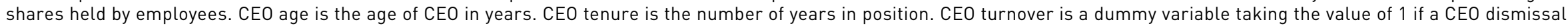

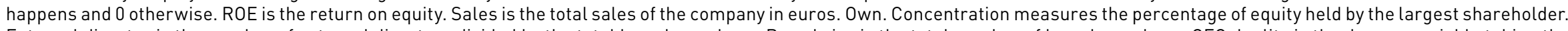

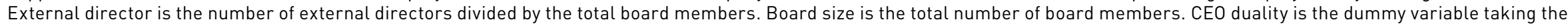

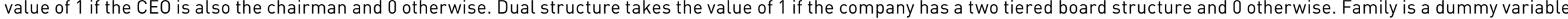
taking the value of 1 if the company is owned by the family and 0 otherwise. State is the dummy variable taking the value of 1 if the state holds shares of the company and 0 otherwise. Tobins

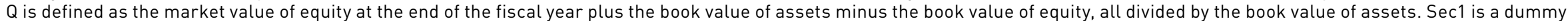

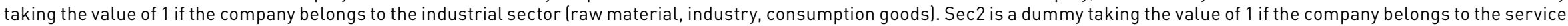
sector (health services, consumer services, telecommunication, services to communities). ${ }^{* * *},{ }^{* *},{ }^{*}$ indicate coefficients significant at the $1 \%, 5 \%$, and $10 \%$ levels, respectively.

\begin{tabular}{|c|c|c|c|c|c|c|c|c|c|c|c|c|c|c|}
\hline & 1 & 2 & 3 & 4 & 5 & 6 & 7 & 8 & 9 & 10 & 11 & 12 & 13 & 14 \\
\hline 1. CEO age & 1 & & & & & & & & & & & & & \\
\hline 2. CEO tenure & $0.05^{*}$ & 1 & & & & & & & & & & & & \\
\hline 3. ESO & 0.05 & -0.09 & 1 & & & & & & & & & & & \\
\hline 4. ROE & -0.02 & $0.17^{* * *}$ & -0.06 & 1 & & & & & & & & & & \\
\hline 5. Sales & $0.22 * * *$ & $-0.03 * * *$ & $0.32 * * *$ & $-0.14^{*}$ & 1 & & & & & & & & & \\
\hline 6. Own. concentration & 0 & $-0.12 * *$ & $-0.18^{* * *}$ & 0.05 & $-0.14^{* *}$ & 1 & & & & & & & & \\
\hline 7. External directors & -0.04 & $0.16^{* *}$ & -0.06 & -0.02 & $0.10^{* * *}$ & $-0.48 * * *$ & 1 & & & & & & & \\
\hline 8. Board size & $0.18^{* * *}$ & $-0.06 * *$ & $0.18^{* * *}$ & -0.05 & $0.49 * * *$ & 0.02 & $-0.28 * * *$ & 1 & & & & & & \\
\hline 9. BEOR & $0.16^{*}$ & $-0.07 * *$ & 0.03 & $-0.10^{* *}$ & $0.24^{* * *}$ & $0.25^{* *}$ & $-0.23 * * *$ & $0.37^{* * *}$ & 1 & & & & & \\
\hline 10. Tobin's Q & 0.01 & 0.1 & $-0.13^{* *}$ & $0.27^{* * *}$ & $-0.26 * * *$ & $0.07 * * *$ & $-0.13^{* * *}$ & $-0.17^{* * *}$ & -0.09 & 1 & & & & \\
\hline 11. CEO turnover & $-0.07^{* *}$ & $-0.34 * * *$ & 0.01 & $-0.15^{* * *}$ & 0.03 & 0.05 & -0.07 & -0.01 & 0.04 & -0.05 & 1 & & & \\
\hline 12. CEO duality & 0.13 & 0.02 & 0.13 & 0.06 & $0.12^{*}$ & -0.01 & $-0.17 *$ & $0.21 * * *$ & $0.12 * *$ & -0.005 & $-0.1^{*}$ & 1 & & \\
\hline 13. Dual Structure & $-0.14^{* *}$ & $-0.14 * * *$ & -0.03 & 0.03 & $0.08 * *$ & -0.05 & $-0.08 * *$ & $0.13^{* * *}$ & -0.08 & -0.07 & -0.009 & $0.18^{* * *}$ & 1 & \\
\hline 14. Family & -0.05 & 0.05 & $-0.20 * * *$ & 0.051 & $-0.29 * * *$ & $0.19 * * *$ & $-0.15^{* * *}$ & $-0.18 * * *$ & $-0.19 * * *$ & $0.2 * * *$ & -0.06 & $-0.09 * * *$ & 0.09 & 1 \\
\hline 15. State & $0.09 * *$ & $-0.03^{*}$ & $0.11^{*}$ & -0.04 & 0.18 & 0.04 & -0.09 & 0.35 & $0.52^{* * *}$ & $-0.1^{* *}$ & 0.03 & 0.03 & -0.005 & $-0.28 * * *$ \\
\hline
\end{tabular}


control variables, the average ownership concentration is $29.05 \%$, $32.77 \%$ and $13.84 \%$ have respectively family or state ownership. $41.34 \%$ of board members are external and the average board size is 12,63 members which is very close to figures reported by Ginglinger et al (2011). 72\% of CEOs also hold the position of chairman of the board and $24 \%$ of companies exhibit a dual structure with a two-tiered board structure. Mean comparison tests are also displayed in the table 2 . We use the median level of ESO (1.03\% of the equity) as a reference point of our comparisons tests. We then compare companies with ESO above (>MED in the table 2) and below this level ( $<$ MED in the table 2$)$. T-tests are significant for the following variables: ROE (+), Sales (-), ownership concentration (+), external directors (-), board size $(-)$, board employee representation (-) meaning that companies with higher levels of ESO tend to have lower ROE, higher sales, lower ownership concentration, more external directors, higher board size and more employee owners on the board. The correlation matrix reported in table 3 does not show high correlations between exogenous variables with the exceptions of the correlation between board size and sales (0.49) and external directors and ownership concentration (-0.48). Although the first correlation seems obvious, the second suggests a substitution effect between ownership concentration that could be compensated by the presence of external directors.

\section{REGRESSION RESULTS}

The data relates to 110 firms over a four-year period (20092012), we apply dynamic panel data econometrics techniques with robust standard errors (Greene, 2012). We report all the coefficients, standard errors and statistics in the tables 3 and 4.

Table 4 displays GMM regressions' estimates of ESO and control variables on $\mathrm{CEO}$ entrenchment measures: $\mathrm{CEO}$ age (models 1 to 3), CEO tenure (models 4 to 6) and CEO turnover (models 7 to 9). For each of these three dependent variables, we use a hierarchical approach where the first model only includes control variables, the second model introduces the ESO variable and the third model includes both the ESO and ESO squared variables in order to test the curvilinear relations. Overall results from models 3, 6 and 9 and the main novelty of this paper is to show the presence of curvilinear relationships between ESO and CEO entrenchment. We use the Lind and Mehlun's (2010) method to check the presence of curvilinear effects and to compute the inflexion points ${ }^{6}$. We find that the inflexion points are the following: $11.73 \%$ for model $3,17.77 \%$ for model $6,11.94 \%$ for model 9. In the model 3, the relation between ESO and CEO age is U-shaped whereas in models 6 and 9 measuring respectively the links between ESO and CEO tenure and between ESO and CEO turnover have the shape of an inverted U. In the case of the regressions on $\mathrm{CEO}$ age, we cannot affirm that the curvilinear effect is validated because the coefficient associated to ESO is only significant at the $10 \%$ level. Regarding the regressions computing the direct effect of ESO on CEO entrenchment, both models 6 \& 9 display significant coefficients with CEO tenure and turnover. Other coefficients associated to our control variables are significant. For the regressions on CEO age (models 1 to 3 ), the following coefficients are significant: external directors $(+)$, board size $(+)$,
CEO duality (-), state (-), Tobin's Q (+) and sales (-). Regressions' coefficients associated to ownership concentration, dual structure, family ownership are not significant. The regressions on CEO tenure (models 4 to 6 ) have the following significant coefficients: ownership concentration (-), external directors $(+)$, board size $(+)$, CEO duality (+), dual structure (-), ROE (+), sales (-) and Tobin's Q (+). Regressions' coefficients associated to ownership concentration, family and state ownership are not significant. For the regressions on CEO turnover (models 7 to 9), the following coefficients are significant: ownership concentration (-), CEO duality ( $<$ for models 7 and 8 and $>0$ for model 9), family ownership (-), ROE (-) and Tobin's Q (+).

Table 5 displays GMM regressions' estimates of BEOR and control variables on CEO entrenchment measures: CEO age (model 10), CEO tenure (model 11) and CEO turnover (model 12). In these regressions, we test the moderating effect of BEOR on the previously investigated relationships between ESO and CEO entrenchment. We do not document a direct significant relationship between BEOR and the three variables of entrenchment i.e. none of the coefficients associated to BEOR is significant. We then test other specifications including interaction effects between ESO and BEOR following Guedri and Hollandts (2008). These authors suggest that BEOR moderates the curvilinear relationship between ESO and performance. They do not validate this hypothesis. Although our approach is very similar from a technical point of view, it differs from theirs in two ways: we do not use performance as the dependent variable but we focus directly of entrenchment and we use BEOR instead of board employee representation of employees whether they are employee owners or not. In this setting, we find significant relationships between our interaction terms $(\mathrm{BEOR} \times \mathrm{ESO}$ and $\mathrm{BEOR} \times \mathrm{ESO} 2)$ and $\mathrm{CEO}$ tenure on one hand and CEO turnover on another. Coefficients associated to the BEOR variable are not significant when CEO age is the dependent variable. Again, the results suggest curvilinear relations. The Lind and Mehlun's (2010) method confirms curvilinear effects and compute the following inflexion points: $11.79 \%$ for model 10 (11.73\% without including BEOR), $17.83 \%$ for model 11 (17.77\% without including BEOR), 12.49\% for model 12 (11.94\% without including BEOR). The results show that BEOR positively moderates the effect of ESO on CEO tenure and CEO turnover. The interpretation of these results is that BEOR decreases the inflexion points of the curvilinear relationship for CEO age (but the coefficients associated to BEOR in this model are not significant) and increases the inflexion points for CEO tenure and turnover (with significant coefficients). Other coefficients associated to our control variables are significant. For the regressions on CEO age (model 10), the following coefficients are significant: ownership concentration (-), dual structure (-), family (+), ROE (+) and Tobin's Q (-). Regressions' coefficients associated to the other variables are not significant. The regressions on CEO tenure (models 11) have the following significant coefficients: external directors $(+)$, board size (+), dual structure (-), family (+), ROE (+) and Tobin's Q (-). Regressions' coefficients associated to the other variables are not significant. For the regressions on CEO turnover (model 12), the following coefficients are significant: ownership concentration (-), dual structure (-), family (-), ROE (-) and Tobin's Q (-).

6. Lind and Mehlun (2010) developed themselves a Stata module to test curvilinear relationships and compute the inflexion points of these relationships. For further details, see: http: //econpapers.repec.org/software/bocbocode/s456874.htm 


\section{TABLE 4 \\ Employee stock ownership and CEO entrenchment}

This table reports the GMM estimates. The dependent variables are the CEO age, the CEO tenure and the CEO turnover. The sample consists of all the SBF 120 Index firms over the period 2009-2012. ESO is the percentage of shares held by employees. ROE is the logarithm of the return on equity. Sales is the logarithm of the total sales of the company in euros. Own. Concentration measures the percentage of equity held by the largest shareholder. External director is the number of external directors divided by the total board members. Board size is the total number of board members. CEO duality is the dummy variable taking the value of 1 if the CEO is also the chairman and 0 otherwise. Dual structure takes the value of 1 if the company has a two tiered board structure and 0 otherwise. Family is a dummy variable taking the value of 1 if the company is owned by the family and 0 otherwise. State is the dummy variable taking the value of 1 if the state holds shares of the company and 0 otherwise. Tobins' $Q$ is defined as the market value of equity at the end of the fiscal year plus the book value of assets minus the book value of equity, all divided by the book value of assets. Sec1 is a dummy taking the value of 1 if the company belongs to the industrial sector (raw material, industry, consumption goods). Sec2 is a dummy taking the value of 1 if the company belongs to the service sector (health services, consumer services, telecommunication, services to communities). The table presents the coefficients, robust standard errors t-values and then the adjusted $\mathrm{R}^{2}$. We report $\mathrm{R}^{2}$ of the fixed-effects OLS regressions. $\mathrm{N}$ is the number of non-missing observations in the sample. ${ }^{* * *},{ }^{* *},{ }^{*}$ indicate coefficients significant at the $1 \%, 5 \%$, and $10 \%$ levels, respectively.

\begin{tabular}{|c|c|c|c|c|c|c|c|c|c|}
\hline & (1) & (2) & (3) & (4) & (5) & (6) & (7) & (8) & (9) \\
\hline & \multicolumn{3}{|c|}{ CEO age } & \multicolumn{3}{|c|}{ CEO tenure } & \multicolumn{3}{|c|}{ CEO turnover } \\
\hline \multirow[t]{2}{*}{ ESO } & & 0.09 & $-1.57 *$ & & -0.02 & $0.16^{* * *}$ & & $-0.02 * *$ & $0.006 * *$ \\
\hline & & (0.30) & $(-1.87)$ & & (0.02) & (0.03) & & $(0.01)$ & (0.003) \\
\hline \multirow[t]{2}{*}{$\mathrm{ESO}^{2}$} & & & $0.081^{* *}$ & & & $-0.007 * * *$ & & & $-0.0004^{*}$ \\
\hline & & & (2.18) & & & $(0.002)$ & & & (0.0002) \\
\hline \multirow[t]{2}{*}{ Own. concentration } & $0.12^{*}$ & $0.12^{*}$ & 0.07 & -0.01 & $-0.01 * * *$ & 0.01 & -0.001 & $-0.003^{* *}$ & $-0.001 * * *$ \\
\hline & $(0.07)$ & $(0.07)$ & (1.27) & $(0.01)$ & (0.003) & $(0.02)$ & (0.001) & (0.001) & $(0.0002)$ \\
\hline \multirow[t]{2}{*}{ External directors } & $0.28 * * *$ & $0.28 * * *$ & $0.20 * * *$ & $0.02 * *$ & $0.01 * * *$ & $0.03 * *$ & -0.002 & -0.004 & -0.0004 \\
\hline & $(0.10)$ & (0.09) & (2.71) & $(0.01)$ & (0.005) & $(0.01)$ & $(0.003)$ & (0.003) & $(0.001)$ \\
\hline \multirow[t]{2}{*}{ Board size } & $6.80 *$ & $6.28 * * *$ & $3.91^{* * *}$ & -0.004 & 0.02 & $0.04^{* * *}$ & -0.013 & -0.01 & -0.02 \\
\hline & (1.98) & (1.71) & $(3.64)$ & $(0.08)$ & (0.02) & $(0.01)$ & $(0.01)$ & $(0.01)$ & (0.02) \\
\hline \multirow[t]{2}{*}{ CEO duality } & $-6.40 * * *$ & $-5.48 *$ & -3.27 & $1.00 *$ & $1.10^{* * *}$ & $1.03^{* * *}$ & $-0.02 * * *$ & $-0.03 * * *$ & $0.16^{* *}$ \\
\hline & (3.62) & (3.14) & $(-1.27)$ & (0.54) & $(0.17)$ & $(0.10)$ & $(0.006)$ & $(0.001)$ & (0.08) \\
\hline \multirow[t]{2}{*}{ Dual Structure } & -4.20 & $-4.23^{*}$ & -3.22 & $-1.52 * * *$ & $4.40 * * *$ & $-1.31 * * *$ & $0.06^{* * *}$ & 0.01 & 0.01 \\
\hline & (2.77) & $(2.24)$ & $(-1.43)$ & (0.52) & $(0.22)$ & $(0.05)$ & $(0.01)$ & $(0.02)$ & $(0.03)$ \\
\hline \multirow[t]{2}{*}{ Family } & -1.96 & -1.76 & -1.43 & 0.0006 & -0.13 & $-0.39 * * *$ & $-0.08^{* * *}$ & $-0.08 * * *$ & $-0.04^{* * *}$ \\
\hline & (3.02) & (2.58) & $(-0.93)$ & $(0.56)$ & (0.25) & $(0.14)$ & $(0.01)$ & $(0.006)$ & $(0.003)$ \\
\hline \multirow[t]{2}{*}{ State } & $-16.62 * * *$ & $-14.30 * * *$ & $-8.29 * *$ & 0.31 & 0.19 & -0.04 & 0.06 & 0.08 & 0.22 \\
\hline & $(6.47)$ & $(2.74)$ & $(-2.00)$ & (0.75) & (0.42) & $(0.35)$ & $(0.11)$ & $(0.12)$ & $(0.20)$ \\
\hline \multirow[t]{2}{*}{ ROE } & -2.03 & -2.23 & -1.57 & $0.56^{*}$ & $0.48^{* * *}$ & $0.50 * * *$ & $-0.09 * * *$ & $-0.07 * *$ & $-0.06^{* * *}$ \\
\hline & (1.62) & (1.69) & $(-1.02)$ & $(0.34)$ & $(0.18)$ & (0.13) & $(0.03)$ & $(0.04)$ & $(0.007)$ \\
\hline \multirow[t]{2}{*}{ Sales } & $-6.32 * * *$ & $-5.89 * * *$ & $-2.76^{* *}$ & -0.13 & $-0.17 * * *$ & $-0.23^{* * *}$ & -0.0008 & 0.02 & -0.003 \\
\hline & $(2.26)$ & (2.02) & $(-2.11)$ & $(0.19)$ & $(0.04)$ & $(0.06)$ & $(0.01)$ & $(0.02)$ & $(0.01)$ \\
\hline \multirow[t]{2}{*}{ Tobin's Q } & 2.17 & 2.06 & $1.54^{* * *}$ & 0.39 & $0.47^{* * *}$ & $0.48^{* * *}$ & $0.04^{* * *}$ & $0.01 * *$ & $0.03^{* * *}$ \\
\hline & (1.76) & (1.62) & $(0.98)$ & (0.32) & $(0.08)$ & $(0.04)$ & $(0.001)$ & (0.007) & $(0.001)$ \\
\hline \multirow[t]{2}{*}{ Sec1 } & $12.90 * * *$ & $13.19 * * *$ & 10.18 & $1.52 * *$ & $1.65^{* * *}$ & $2.03 * * *$ & -0.09 & -0.10 & -0.10 \\
\hline & $(4.60)$ & (4.22) & (3.01) & (0.69) & (0.29) & $(0.48)$ & $(0.11)$ & $(0.10)$ & $(0.07)$ \\
\hline \multirow[t]{2}{*}{ Sec2 } & $14.33^{* * *}$ & $13.36^{* * *}$ & $10.22 * * *$ & -0.45 & -0.15 & 0.10 & -0.09 & -0.04 & -0.12 \\
\hline & (5.32) & (4.72) & $(2.64)$ & $(0.67)$ & $(0.10)$ & $(0.27)$ & (0.13) & $(0.10)$ & $(0.11)$ \\
\hline \multirow[t]{2}{*}{ Constant } & $51.36^{* * *}$ & $50.80 * * *$ & $39.39 * * *$ & 4.11 & $-1.52^{* * *}$ & $3.34^{* *}$ & $0.66^{* *}$ & $0.46^{*}$ & $0.50 * * *$ \\
\hline & $(15.96)$ & (14.83) & $(2.85)$ & $(3.00)$ & (1.26) & $(1.56)$ & (0.33) & $(0.24)$ & $(0.054)$ \\
\hline $\mathbf{R}^{2}$ & 0.16 & 0.16 & 0.16 & 0.15 & 0.15 & 0.15 & 0.06 & 0.06 & 0.06 \\
\hline J-statistique (p-value) & 0.32 & 0.29 & 0.05 & 0.59 & 0.20 & 0.33 & 0.36 & 0.45 & 0.63 \\
\hline $\mathrm{Nb}$ of instruments & 18 & 20 & 23 & 18 & 20 & 19 & 18 & 18 & 23 \\
\hline Observations & 229 & 238 & 149 & 238 & 229 & 230 & 149 & 149 & 148 \\
\hline
\end{tabular}




\section{TABLE 5}

\section{Employee stock ownership, CEO entrenchment and representation of employee owners on the board}

This table reports the GMM estimates. The dependent variables are the CEO age, the CEO tenure and the CEO turnover. The sample consists of all the SBF 120 Index firms over the period 2009-2012. ESO is the percentage of shares held by employees. BEOR is the proportion of employee owners seating on the board. ROE is the logarithm of the return on equity. Sales is the logarithm of the total sales of the company in euros. Own. Concentration measures the percentage of equity held by the largest shareholder. External director is the number of external directors divided by the total board members. Board size is the total number of board members. CEO duality is the dummy variable taking the value of 1 if the CEO is also the chairman and 0 otherwise. Dual structure takes the value of 1 if the company has a two tiered board structure and 0 otherwise. Family is a dummy variable taking the value of 1 if the company is owned by the family and 0 otherwise. State is the dummy variable taking the value of 1 if the state holds shares of the company and 0 otherwise. Tobins' $Q$ is defined as the market value of equity at the end of the fiscal year plus the book value of assets minus the book value of equity, all divided by the book value of assets. Sec1 is a dummy taking the value of 1 if the company belongs to the industrial sector (raw material, industry, consumption goods). Sec2 is a dummy taking the value of 1 if the company belongs to the service sector (health services, consumer services, telecommunication, services to communities). The table presents the coefficients, robust standard errors $\mathrm{t}$-values. We report R2 of the fixed-effects OLS regressions. $\mathrm{N}$ is the number of non-missing observations in the sample. ${ }^{* * *},{ }^{* *},{ }^{*}$ indicate coefficients significant at the $1 \%, 5 \%$, and $10 \%$ levels, respectively.

\begin{tabular}{|c|c|c|c|}
\hline & (10) & (11) & [12] \\
\hline & CEO age & CEO tenure & CEO turnover \\
\hline \multirow[t]{2}{*}{ ESO } & $-2.36 * * *$ & $-0.32^{* * *}$ & $-0.03 * * *$ \\
\hline & (0.17) & $(0.04)$ & (0.01) \\
\hline \multirow[t]{2}{*}{$\mathrm{ESO}^{2}$} & $0.07 * * *$ & $0.02^{* *}$ & $0.001 * * *$ \\
\hline & $(0.00)$ & $(0.00)$ & $(0.00)$ \\
\hline \multirow[t]{2}{*}{ BEOR } & $-62.19 * * *$ & $-11.19 * * *$ & $-1.82 * * *$ \\
\hline & $(25.45)$ & (1.32) & $(0.51)$ \\
\hline \multirow{2}{*}{ BEOR*ESO } & 8.89 & $6.37 * * *$ & $0.96 * * *$ \\
\hline & (13.13) & (0.39) & (0.22) \\
\hline \multirow[t]{2}{*}{$\mathrm{BEOR}^{*} \mathrm{ESO}^{2}$} & -0.23 & $-0.25^{* * *}$ & $-0.04^{* * *}$ \\
\hline & (0.52) & $(0.00)$ & (0.01) \\
\hline \multirow[t]{2}{*}{ Own. concentration } & $-0.16^{* * *}$ & 0.01 & $-0.003 * * *$ \\
\hline & $(0.00)$ & $(0.02)$ & $(0.001)$ \\
\hline \multirow[t]{2}{*}{ External directors } & -0.02 & $0.08^{* * *}$ & -0.005 \\
\hline & $(0.12)$ & (0.02) & $(0.003)$ \\
\hline \multirow[t]{2}{*}{ Board size } & 1.24 & $0.11 * *$ & -0.03 \\
\hline & (1.19) & $(0.05)$ & (0.02) \\
\hline \multirow[t]{2}{*}{ CEO duality } & 11.50 & $1.41 * * *$ & $-0.01 *$ \\
\hline & $(16.04)$ & $(0.16)$ & (0.01) \\
\hline \multirow[t]{2}{*}{ Dual Structure } & $-39.22 * * *$ & $-1.44 * * *$ & $-0.05^{* * *}$ \\
\hline & (7.85) & (0.35) & (0.01) \\
\hline \multirow[t]{2}{*}{ Family } & $4.87^{* * *}$ & $0.32 * * *$ & $-0.06 * * *$ \\
\hline & (1.31) & (0.12) & (0.03) \\
\hline \multirow[t]{2}{*}{ State } & -1.46 & $0.70^{*}$ & 0.10 \\
\hline & (5.07) & (0.38) & $(0.10)$ \\
\hline \multirow[t]{2}{*}{ ROE } & $1.27 * * *$ & $0.27^{* * *}$ & $-0.09 * * *$ \\
\hline & (0.07) & (0.07) & (0.03) \\
\hline \multirow[t]{2}{*}{ Sales } & 1.24 & $-0.33 * * *$ & 0.02 \\
\hline & $(1.32)$ & (0.03) & (0.02) \\
\hline \multirow[t]{2}{*}{ Tobin's Q } & $-3.46 * * *$ & $0.44^{* * *}$ & $-0.01 * * *$ \\
\hline & $(0.26)$ & $(0.14)$ & $(0.00)$ \\
\hline \multirow[t]{2}{*}{ Sec1 } & $2.33^{* *}$ & $2.04^{* * *}$ & -0.13 \\
\hline & $(1.07)$ & $(0.69)$ & $(0.11)$ \\
\hline \multirow[t]{2}{*}{ Sec2 } & $6.19 * * *$ & 0.02 & -0.11 \\
\hline & (0.02) & (0.29) & $(0.12)$ \\
\hline \multirow[t]{2}{*}{ Constant } & $31.23^{* * *}$ & 2.47 & $0.71 * * *$ \\
\hline & (7.78) & (3.20) & $(0.26)$ \\
\hline $\mathbf{R}^{2}$ & 0.16 & 0.15 & 0.07 \\
\hline J-statistique (p-value) & 0.06 & 0.18 & 0.67 \\
\hline Nb of instruments & 19 & 28 & 24 \\
\hline Observations & 150 & 148 & 150 \\
\hline
\end{tabular}




\section{Robustness Checks}

We run additional tests to check the sensitivity of our analyses to alternative explanations. Endogeneity is an important concern for research in corporate governance and surely affect the relationship between ESO, BEOR and CEO entrenchment. But it is treated thanks to the GMM regressions. Also, some variables potentially affect the relation between ESO and BEOR and CEO entrenchment. We include three additional variables and run the GMM regressions: total debt, CEO social capital and CEO human capital. Literature in corporate finance argues that debt may play a disciplinary role by reducing management discretionary power (Jensen, 1986). Previous papers in corporate governance suggest that CEO human and social capital affect corporate governance (Johnson et al, 2012). We measure the total debt as the total debt issued by the firm in Euros (source: Thomson Reuters Eikon), the human capital with a dummy variable taking the value of 1 when a CEO graduated from Ecole Nationale d'Administration, Ecole Polytechnique or Hautes Etudes Commerciales and 0 otherwise (source: IODS), the social capital is the total number of board of directors mandates in French listed companies hold by the CEO. The coefficients associated with these three variables are not significant in most of the models. We therefore choose not to include these variables in the reported tables. We interpret these results as a consequence of the variance of CEO entrenchment explained by these variables as already captured by other variables. Debt is very correlated with other financial and accounting characteristics such as the size of the company, the ROE and the Tobin's Q already in our regressions. CEO human and social capital are very related to other variables we already have in our regressions such as ownership variables or governance variables. We also tried alternative combinations of variables and we only keep and report the models that provides the best results in terms of model fit and significance. Finally, we run regressions including CEO age and CEO tenure as independent variables following Goyal and Park (2002). The results remain the same.

\section{Discussion}

In this paper, we focus on the relationship between employee stock ownership (ESO), its potential representation into the board (BEOR) and corporate governance. Only few papers have suggested that ESO can be part of a broader form of employee power namely employees' voice. In the French context, employee owners have a fraction of capital but can also be (compulsorily) appointed at board level. Guedri and Hollandts (2008) and Ginglinger et al (2011) have examined the impact of such representation and found mixed results. Thus, there is a theoretical and empirical debate in the corporate governance literature about the impact of ESO. We take into account the two literature streams and suggest that ESO and BEOR exhibit two opposite forces. The "bright" side suggests that ESO and its potential board membership increases transparency, decreases the level of asymmetric information and ensures more efficient corporate governance mechanisms. ESO is often viewed as a management and financial tool that increases corporate performance, decreases labor conflicts and finances corporate growth. But as suggested by the other stream, ESO can be seen as a powerful entrenchment tool that helps CEOs to extend their tenure and repel threats of dismissal (through market for corporate control). In addition, significant ESO levels push away rather towards shareholder-value maximization (Faleye et al, 2006). Combining two latent and countervailing linear functions (see Haans et al, 2016 for further details), we suggest that the bright and dark side of ESO translate into a non-monotonic relationship with our focal variable, namely $\mathrm{CEO}$ entrenchment. In this paper, we focus mainly on CEO entrenchment since the corporate governance literature has shown that the CEO function is central for corporate governance efficiency (Joseph et al, 2014; Tihanyi et al, 2014).

To our knowledge, our paper is the first to empirically test the focal relationship in the French context since the adoption of (legal) compulsory BEOR. France offers a unique perspective to test a mix of voluntary ESO mechanisms (French ESO schemes are based on voluntary participation) and compulsory mechanism (BEOR). The French context represents a hybrid, and somewhat unique case, apart from US corporate governance system (with no board employee board membership) or German codetermination regime (with compulsory trade-union board membership (Aste, 1999; Ginglinger et al, 2011; see also Tihanyi et al, 2014 for a discussion). Nevertheless, we believe that our results are generalizable to other advanced economies for several reasons. Ginglinger et al (2011) underline that French listed companies, are comparable firms with in all European and North American countries since these firms are highly visible companies operating in competitive global industries. In addition, the capital breakdown of French listed companies is diversified and internationalized as non-French investors own over half of the stock of private companies (Ginglinger et al, 2011). The unique mix of ESO participation and compulsory board employee owners' appointments in France give us the opportunity to test two dimensions of employees' power (by collectively holding a fraction of capital and/or a seat into the board of directors).

Our paper also contributes to the empirical literature since significant evidence of the relationship between employee ownership's voice and CEO entrenchment is highlighted. Our models reveal non-monotonic relationships between ESO and $\mathrm{CEO}$ entrenchment (measured by CEO age, CEO tenure and CEO turnover). Additional tests also show that BEOR moderates the ESO - CEO entrenchment relationship, for two dimensions of CEO entrenchment (CEO tenure and turnover), by fostering the impact of ESO on CEO entrenchment. Results from model 3,6 and 9 provide a strong support for our first hypothesis. We mainly observed a significant inverted U-shaped relationship between ESO and CEO entrenchment. Results from models 6 and 9 underline that ESO could be an interesting tool for CEOs who want to enhance their entrenchment. Our results also show a curvilinear (U-shaped) relationship between ESO and CEO age. Taken together, our results suggest that ESO can be an effective entrenchment tool, up to a certain point. Beyond the inflexion points, CEOs must be well entrenched and/or other governance mechanisms may be at play. Regarding CEO age, our results suggest that ESO could be less interesting for CEOs near retirement but could be more profitable for CEOs that go beyond the retirement age. Nevertheless, further research 
is clearly needed to go deeper in the understanding of such an apparent "paradox".

Results from models 10 to 12 provide also a strong support for our second hypothesis. For these models, our results highlight the presence of significant and positive moderating impact of BEOR. Our results show that ESO and BEOR contribute to explain our variables capturing CEOs' entrenchment. Our results underline the combined effect of employee voice consisting in stock ownership and board membership. By giving additional voice (board membership), ESO offers an additional tool that give a potential entrenchment tool to CEOs. Theoretically, employee owners may more easily enter into implicit contracts with CEOs (Pagano and Volpin, 2005) in return for favorable corporate policies (Cronqvist et al, 2009; Acharya et al, 2011). Broadly speaking, recent papers in the literature point out non-monotonic relationships between ESO and corporate performance or corporate governance variables (Faleye and al, 2006; Guedri and Hollandts, 2008; Kim and Ouimet, 2014) and our paper gives new evidence on the mixed impact of ESO. Our purpose was to fill a gap in the literature, showing that ESO affects CEO entrenchment, and not only in specific cases of takeover threats. ESO is mainly considered in the literature as a "friendly" fraction of capital for CEOs (Gamble, 2000) but few papers have tried to examine empirically the impact on corporate governance except in special cases such as takeover and broadly the market for corporate control (Kim and Ouimet, 2014). Our paper tries to test the impact of ESO in regular corporate governance context. Furthermore, we provide additional test of BEOR and highlight the moderating impact of such board representation.

Overall results (from direct and moderating effects) are interpreted as an evidence of bilateral entrenchment since employee owners are incentivized to maintain implicit contracts with their CEO until he/she retires. To the best of our knowledge, our results could also be interpreted with regard to former empirical studies in the French context. Guedri and Hollandts (2008) have shown the curvilinear impact of ESO on firm performance for a larger index of listed companies (SBF 250). However, they do not find support for BEOR whereas our results suggest that BEOR plays a role. Moreover, our results somewhat contrast with findings of Ginglinger et al (2011). Indeed, their observations show that board employee representation could at least appear value-neutral, and in some circumstances value-enhancing for firm performance. They found "that directors elected by employee shareholders increase firm valuation and profitability, but do not significantly impact corporate payout policy" (Ginglinger and al, 2011; p. 868).

Our results highlight the mixed impact of ESO. Some authors have stressed the dark side of employee voice regarding corporate policies (Chen et al, 2012; Faleye et al, 2006) whereas employee voice may also be seen as an internal governance system (Acharya et al, 2011) that contributes to increase the level of transparency (Bova et al, 2015). From a corporate governance perspective, recent papers argue that ESO and employee voice still play a major role in terms of managerial entrenchment (Aubert et al, 2014). We do not directly test the impact on corporate performance or profitability but our results show that for corporate governance considerations, ESO exhibits mixed impacts since it contributes to foster CEO entrenchment in some circumstances. Thus our paper contributes to our overall understanding of the full consequences of ESO.

Combining overall results in the literature, we assert, as Fauver and Fuerst (2006), that ESO may enhance productivity, corporate performance and firm value (Kaarsemaker, 2006), though, in some cases, excessive levels of ESO may have a dark side, with potential negative impacts on CEO entrenchment. This notion of excessive levels of ESO is reflected in recent literature, suggesting that an optimal balance should be reached (Aubert et al, 2014; Kim and Ouimet, 2014; Guedri and Hollandts, 2008; Faleye et al, 2006). Our results, showing non-mononotic relationships, give new evidence on the likelihood of optimal configuration of ESO, regarding corporate performance and corporate governance considerations.

Our results have also managerial implications. In France, as in many developed countries, ESO is increasing and is well developed. For example, 23 Millions of American are employee owners $(20 \%$ of total employee workforce - National Center for ESO, 2014). In France, 3.5 Millions of French employees hold their company stocks. Thus, we need to clearly examine the full consequences of ESO on corporate governance since this phenomenon is still increasing. If the balance shifts in the right (bright) side, main stakeholders will give strong support to such ESO schemes. If not, we can expect that executive managers and main shareholders will prefer to slow down its current development. In our sample, the mean for firms with ESO is $2.4 \%$ of equity, not far from the $3 \%$ threshold of compulsory BEOR. Thus, external shareholders must carefully examine full consequences of ESO development within the firm and its capital breakdown.

Even though this paper contributes to the literature on ESO and corporate governance, it has several limitations. First, our study is limited to the largest French listed companies by focusing on the 120 biggest capitalizations. We acknowledge that ESO can be implemented in non-listed firms but for France, 99,6\% of ESO is concentrated in listed companies (DARES - Statistics Institute of the French Ministry of Labour). Another interesting point for the SBF 120 is that this index is well balanced since almost half of this index is composed with companies that have implemented ESO schemes. Second, our study only spans on four years since we precisely start our study the year BEOR became compulsory. Consequently, our results must be interpreted cautiously. We think that the continuous development of ESO will help to confirm our results.

Further research is nevertheless needed to facilitate deeper understanding of what would be the potential combination of overall employee voice (through ESO) and BEOR. Except for Germany and the co-determination system, which is well documented in the literature (Fauver and Fuerst, 2006; Kim et al, 2014), we obtained fragmented empirical results based on hybrid cases such as the French system (Guedri and Hollandts, 2008; Ginglinger et al, 2011). Some authors explore the potential combination of employee voice in terms of shareholding power and board representation. Another interesting stream in corporate governance literature can focuses on the employee power into the board. For instance, a recent paper from Balsmeier et al (2013), using game-theoretical and 
political models give us an opportunity to examine power relationships in the boardroom in the presence of employee (ownership) representation. To sum up, it seems obvious that in the current context a substantial part of employee voice lies in shareholding power, since board employee representation is modest ${ }^{7}$. Nevertheless, comparisons with the current German co-determination system should be made with caution because the French institutional and legal environment are different, and results obtained with German parity firms should be interpreted taking into account their specific context.

An important avenue for future research obviously regards the financial literature. CEOs are strongly incentivized to establish implicit contracts with employee owners (Hellwig, 2000; Pagano and Volpin, 2005). Recent papers (Aubert et al, 2014) underline the fact that ESOs may be a powerful tool for CEOs in addition to being a financing mean, which can be attractive both for low-performing CEOs or newly appointed ones. Further research is also required regarding the determinants of corporate financing policies (CEO decision-making). Is ESO an optimal tool allowing to finance corporate growth and helping guard CEOs and firms against hostile takeovers?

\section{Conclusion}

This study examines how ESO and BEOR affects CEO entrenchment. The French case is interesting in that it combines a mandatory board employee representation with a widespread ESO culture among listed firms. A comprehensive sample was used to assess the impact of ESO and BEOR on CEO entrenchment. Findings indicate that ESO exhibits non-monotonic (curvilinear) relationships with $\mathrm{CEO}$ entrenchment. Other tests underline that BEOR plays a substantial role by providing CEOs an additional entrenchment tool. Overall results show that ESO may be seen as a double-edged sword. On one hand, previous research has clearly documented a positive impact at the micro-level of organizations (implication, satisfaction, productivity, psychological ownership, etc.). On the other hand, corporate governance literature questions the impact of employee voice on corporate governance and corporate valuation. Acharya et al (2011) argue that a model of "internal governance", where subordinate managers monitor top management, may mitigate agency problems. However, ESO and boardlevel employee representation may operate as an insurance mechanism (Kim et al, 2014) that ensures the enforcement of implicit contracts (Pagano and Volpin, 2005).

Following Fauver and Fuerst (2006), we argue that excessive levels of employee voice, tend to impact labor itself, which becomes an agency cost. Indeed, employees pursue their own interests, exert their influence to maximize payroll rather than stock price, creating a situation in which monitors themselves need to be monitored. This concept of "excessive" employee voice has been described in the late literature, showing that the development of ESO must be carefully managed.

\section{References}

Acharya, Viral V.; Myers, Stewart C.; Rajan, Raghuram G (2011). "The Internal Governance of Firms", Journal of Finance, vol. 66, $\mathrm{n}^{\circ} 3$, p. 689-720.

Adams, Renee B.; Ferreira, Daniel (2007). "A theory of friendly boards”, The Journal of Finance, vol. 62, n¹, p. 217-250.

Adams, Renee B.; Hermalin, Benjamin E.; WEISBACH, Michael $S$ (2010). "The role of boards of directors in corporate governance: A conceptual framework and survey", Journal of Economic Literature, vol. $48, \mathrm{n}^{\circ} 1$, p. 58-107.

Arellano, Manuel; Bond, Stephen (1991). "Some tests of specification for panel data: Monte Carlo evidence and an application to employment equations", The review of economic studies, vol.58, $\mathrm{n}^{\circ} 2$, p. 277-297.

Aste, Laura J. (1999). "Reforming French corporate governance: A return to the two-tier board", George Washington journal of international law and economics, vol. $32, \mathrm{n}^{\circ} 1$.

Atanassov, Julian; Kim, E Han (2009). "Labor and Corporate Governance: International Evidence from Restructuring Decisions", Journal of Finance, vol. 64, n 1, p. 341-374.

Aubert, Nicolas; Garnotel, Guillaume; LAPIED, André; Rousseau, Patrick (2014). "Employee ownership: A theoretical and empirical investigation of management entrenchment vs. reward management”, Economic Modelling, vol. 40, p. 423-434.

Balsmeier, Benjamin; Bermig, Andreas, \& Dilger, Alexander (2013). "Corporate governance and employee power in the boardroom: An applied game theoretic analysis", Journal of Economic Behavior \& Organization, vol. 91, p. 51-74.

BEATTy, Ann (1995). "The cash flow and informational effects of employee stock ownership plans", Journal of Financial Economics, vol. $38, n^{\circ} 2$, p. 211-240.

Benartzi, Shlomo.; THALER, Richard. H., UTKUS, Stephen P.; SUNSTEIN, Cass R. (2007). "The law and economics of company stock in 401 (k) plans", Journal of law and economics, vol. $50, \mathrm{n}^{\circ} 1$, p. $45-79$.

Bertrand, Marianne, \& Mullainathan, Sendhil (2003). "Enjoying the Quiet Life? Corporate Governance and Managerial Preferences", Journal of Political Economy, vol. 111, n 5, p. 1043-1075.

Bhagat, Sanjay; JefFeris, Richard H. (2005). The econometrics of corporate governance studies: MIT Press.

Blair, Margaret M.; Kruse, Douglas L.; Blasi, Joseph R (2000). "Employee ownership: an unstable form or a stabilizing force?", in M. M. K. Blair, Thomas A. (Ed.), The new relationship: human capital in the American corporation (p. 241-298). Washington D.C.: Brookings Institution Press.

Blair, Margaret M.; Roe, Mark J. (Eds.). (1999). Employees and corporate governance. Washington, DC: Brookings Institution Press.

Blundell, Richard; Bond, Stephen (1998). "Initial conditions and moment restrictions in dynamic panel data models", Journal of econometrics, vol. 87, $\mathrm{n}^{\circ} 1$, p. 115-143.

Boone, Audra L.; Casares Field, Laura; Karpoff, Jonathan M.; RAHEJA, Charu G (2007). “The determinants of corporate board size and composition: An empirical analysis”, Journal of Financial Economics, vol. 85, n 1, p. 66-101. 
Bova, Francisco, Dou, Yiwei; Hope, Ole-Kristian (2015). "Employee ownership and firm disclosure", Contemporary Accounting Research, vol. 32, n², p. 639-673.

Castanias, Richard P.; Helfat, Constance E (1992). "Managerial and windfall rents in the market for corporate control", Journal of Economic Behavior \& Organization, vol. 18, $\mathrm{n}^{\circ} 2$, p. 153-184.

Castanias, Richard P.; Helfat, Constance E. (2001). “The managerial rents model: theory and empirical analysis", Journal of Management, vol. 27, p. 661-678.

Chang, Saeyoung (1990). "Employee stock ownership plans and shareholder wealth: an empirical investigation”, Financial Management, vol. 19, $\mathrm{n}^{\circ} 1$, p. 48-58.

Chang, Saeyoung; Mayers, David (1992). “Managerial vote ownership and shareholder wealth: evidence from employee stock ownership plans", Journal of Financial Economics, vol. 32, n 1 , p. 103-131.

Chaplinsky, Susan; Niehaus, Greg (1994). "The role of ESOPs in takeover contests", Journal of Finance, vol. 49, $\mathrm{n}^{\circ} 4$, p. 1451-1470.

Chen, Huafeng; KacPerczyK, Martin; Ortiz-Molina, Hernan (2012). "Do Nonfinancial Stakeholders Affect the Pricing of Risky Debt? Evidence from Unionized Workers", Review of Finance, vol. 16, n² 2 , p. 347-383.

Cramton, Peter; Mehran, Hamid; Tracy, Joseph (2008). “ESOP Fables: The Impact of Employee Stock Ownership Plans on Labor Disputes. Federral Reserve Bank of New York.

Crongvist, Henrik; Heyman, Fredrik; Nilsson, Mattias; Svalerry, Helena; Vlachos, Jonas (2009). "Do Entrenched Managers Pay Their Workers More?”, Journal of Finance, vol. 64, n 1 , p. 309-339.

Faleye, Olunbunmi (2007). "Classified boards, firm value, and managerial entrenchment”, Journal of Financial Economics, vol. $83, \mathrm{n}^{\circ} 2$, p. 501-529.

Faleye, Olunbunmi, Mehrotra, Vikash; Morck, Randall (2006). "When labor has a voice in corporate governance", Journal of Financial \& Quantitative Analysis, vol. 41, n³, p. 489-510.

Fauver, Larry; Fuerst, Michael E. (2006). "Does good corporate governance include employee representation? Evidence from German corporate boards", Journal of Financial Economics, vol. $82, \mathrm{n}^{\circ} 3$, p. $673-710$.

Fisman, Ray J.; Khurana, Rakesh; Rhodes-KROPF, Matthew; YIM, Soojin (2013). "Governance and CEO turnover: Do something or do the right thing?", Management Science, vol. $60, \mathrm{n}^{\circ} 2$, p. 319-337.

GAMBLE, John E. (2000). "Management commitment to innovation and ESOP stock concentration", Journal of Business Venturing, vol. $15, \mathrm{n}^{\circ} 5-6$, p. 433-447.

Ginglinger, Edith; Megginson, William; Waxin, Timothee (2011). "Employee ownership, board representation, and corporate financial policies", Journal of Corporate Finance, vol. 17, n 4 , p. $868-887$.

Gordon, Lilli A.; Pound, John (1990). "ESOPs and corporate control”, Journal of Financial Economics, vol. 27, n², p. 521-551.

Goyal, Vikas. K.; PARK, Chul W (2002). "Board leadership structure and CEO turnover", Journal of Corporate Finance, vol. 8, ${ }^{\circ} 1$, p. 49-66.
Greene, William H. (2012). Econometric analysis (7th ed., International ed.). Boston: Pearson.

Gregory-Smith, Ian; Thompson, Steve; Wright, Peter W (2009). "Fired or retired? A competing risks analysis of chief executive turnover", the Economic Journal, vol. 119, n536, p. 463-481.

Guedri, Zied; Hollandts, Xavier (2008). "Beyond dichotomy: the curvilinear impact of employee ownership on firm performance", Corporate Governance: An International Review, vol. 16, n 5 , p. 460-474.

HaAns, Richard F.; Pieters, Constant; He, Zi-Lin (2016). “Thinking about $\mathrm{U}$ : theorizing and testing $\mathrm{U}$-and inverted $\mathrm{U}$-shaped relationships in strategy research", Strategic Management Journal, vol 37, nº, p. 1177-1195.

HELLWIG, Martin (2000). "On the economics and politics of corporate finance and corporate control”, in Vives X. (Ed.), Corporate Governance: Theoretical and Empirical Perspectives. Cambridge, UK: Cambridge University Press.

Hermalin, Benjamin E.; Weisbach, Michael S (2000). Boards of Directors as an Endogenously Determined Institution: A Survey of Economic Literature. Working Paper.

Hill, Charles W. L.; PHan, Phillip (1991). "CEO tenure as a determinant of CEO pay”, Academy of Management Journal, vol. 34, $\mathrm{n}^{\circ} 3$, p. 707-717.

Hill, Charles W. L., \& Snell, Scott A (1988). "External control, corporate strategy, and firm performance in research-intensive industries", Strategic Management Journal, vol. 9, nº, p. $577-590$.

Jensen, Michael C (1986). “Agency cost of free cash flow, corporate finance, and takeovers", American Economic Review, vol. 76, n'2, p. 323-329.

Johnson, Scott G.; Schnatterly, Karen; Hill, Aaron D (2012). "Board composition beyond independence social capital, human capital, and demographics", Journal of Management, vol 39, $\mathrm{n}^{\circ} 1$, p. 232-262.

Joseph, John; Ocasio, William; McDonnell, Mary-Hunter (2014). "The structural elaboration of board independence: Executive power, institutional logics, and the adoption of CEO-only board structures in US corporate governance", Academy of Management Journal, vol. 57, nº, p. 1834-1858.

KAARSEMAKer, Erik (2006). Employee ownership and its consequences: synthesis-generated evidence for the effects of employee ownership and gaps in the research literature. University of York.

Kim, E Han; MaUg, Ernst G.; Schneider, Christoph (2014). "Labor representation in governance as an insurance mechanism", European Corporate Governance Institute (ECGI)-Finance Working Paper (411).

Kim, E. Han; Ouimet, Paige (2014). "Broad-based employee stock ownership: motives and outcomes", Journal of Finance, vol. 69, $\mathrm{n}^{\circ} 3$, p. 1273-1319.

Kruse, Douglas; Freeman, Richard B.; Blasi, Joseph R. “(2010). Shared capitalism at work: employee ownership, profit and gain sharing, and broad-based stock options", National Bureau of Economic Research conference report. Chicago: The University of Chicago Press.

Linck, James S.; Netter, Jeffry M.; \& YAng, Tina (2008). “The determinants of board structure", Journal of Financial Economics, vol. $87, \mathrm{n}^{\circ} 2$, p. $308-328$. 
LIND, Jo T., \& MEHLUM, Halvor (2010). "With or without U? the Appropriate Test for a U-Shaped Relationship", Oxford bulletin of economics and statistics, vol. 72, n ${ }^{\circ}$, p. 109-118.

McConnell, John J.; Servaes, Henri (1990). “Additional evidence on equity ownership and corporate value”, Journal of Financial Economics, vol. 27, $\mathrm{n}^{\circ} 2$, p. 595-612.

Pagano, Marco; Volpin, Paolo F (2005). "Managers, workers, and corporate control”, Journal of Finance, vol. 60, $\mathrm{n}^{\circ} 2$, p. 841-868.

PArk, Saeyoung., \& Song, Moon H (1995). “Employee stock ownership plans, firm performance, and monitoring by outside blockholders", Financial Management, vol. 24, n 4 , p. $52-65$.

Pugh, William N.; Oswald, Sharon L.; \& JAhera Jr., J. S (1999). "ESOPs, Takeover Protection, and Corporate Decision-Making", Journal of Economics and Finance, vol. 23, n² 2, p. 170-185.

Raheja, Charu G (2005). "Determinants of Board Size and Composition: A Theory of Corporate Boards", Journal of Financial \& Quantitative Analysis, vol. 40, n², p. 283-306.

RAPP, Thomas; Aubert, Nicolas (2011). "Bank employee incentives and stock purchase plans participation”, Journal of Financial Services Research, vol. 40, n³, p. 185-203.
RaUH, Joshua D (2006). "Own company stock in defined contribution pension plans: A takeover defense?”, Journal of Financial Economics, vol. 81, n², p. 379-410.

Scholes, Miron S.; Wolfson, Mark A (1990). "Employee stock ownership plans and corporate restructuring: myths and realities", Financial Management, vol. 19, n¹, p. 12-28.

Semadeni, Matthew, Withers, Michael C., \& Certo Trevis S. (2014). "The perils of endogeneity and instrumental variables in strategy research: Understanding through simulations", Strategic Management Journal, vol. 35, nº, p. 1070-1079.

Timanyi, Laszlo, Graffin, Scott, \& George, Gerard (2014). "Rethinking governance in management research", Academy of Management Journal, vol. 57, n6, p. 1535-1543.

Wintoki, Babajide M.; LINCK, James S.; NetTer, Jeffry M (2012). "Endogeneity and the dynamics of internal corporate governance", Journal of Financial Economics, vol. 105, n³, p. 581-606.

YermaCK, David (1996). "Higher market valuation of companies with a small board of directors", Journal of Financial Economics, vol. $40, \mathrm{n}^{\circ} 2$, p. $185-211$.

YI Tsung, Lee; Yu-Jane, Liu; Ning, Zhu (2008). “The Costs of Owning Employer Stocks: Lessons from Taiwan”, Journal of Financial \& Quantitative Analysis, vol. 43, n³, p. 717-740. 